\title{
EDITORIAL
}

\section{0 años divulgando la agricultura del desierto}

\author{
50 years of disseminating desert agriculture
}

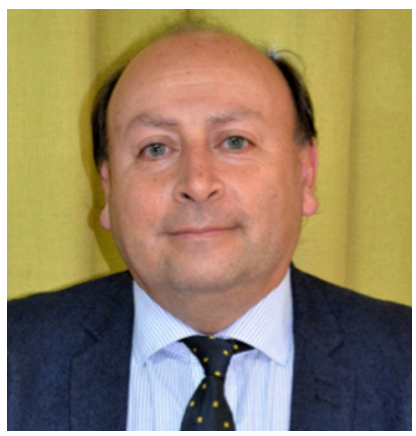

Alfonso Díaz Aguad

Vicerrectoría Académica, Universidad de Tarapacá, Arica, Chile.

adiaz@academicos.uta.cl

El 15 de octubre de 1958, a fines del gobierno del presidente Carlos Ibáñez del Campo, se publica en el diario oficial la Ley 13.039 cuyo primer artículo dice:

Créase una persona jurídica de derecho público, que se denominará "junta de Adelanto de Arica", encargada de fomentar la producción y, en general, el progreso del departamento de Arica, de acuerdo a las disposiciones de la presente Ley.

Esta ley fue impulsada por el presidente Ibáñez, al considerar que el Puerto Libre de Arica, también creado durante su gobierno, si bien es cierto había promovido el comercio, no garantizaba el desarrollo sustentable de la ciudad a largo plazo. La Junta de Adelanto de Arica estaba compuesta por el gobernador de la provincia, el alcalde de Arica y los líderes de los gremios más representativos de la comuna, que se encargaban de:

Estudiar, disponer, coordinar y poner en plan de realización todas las obras que se estimen necesarias para el adelanto rural y urbano del departamento de Arica; para el fomento de susfuentes de producción; para el incremento de su comercio, y para el bienestar general de sus habitantes.
On October 15 $5^{\text {th }}, 1958$, at the end of President Carlos Ibáñez del Campo's government, Law 13,039 was published in the official newspaper, the first article of which reads.

A legal entity of public Law is created, called "Junta de Adelanto de Arica", in charge of promoting the production and, in general, the progress of the department of Arica to the provisions of this Law.

This Law was promoted by President Ibañez, who considered that the Free Port of Arica, also created during his government, although it had promoted trade, did not guarantee the long-term sustainable development of the city. The "Junta de Adelanto" (Board of Advancement of Arica) was composed of the province governor, the mayor of Arica, and the leaders of the most representative unions of the city, who were in charge of:

To study, arrange, coordinate, and to put in a plan of completion all the works considered necessary for the rural and urban advancement of the department of Arica; for the promotion of its production sources; commerce increase, and the general well-being of its inhabitants. 
En este contexto, por iniciativa de la Junta de Adelanto de Arica, el 9 de octubre de 1963 se crea el Laboratorio de Investigación y Control de Plagas. Luego, en 1966, se transformó en el Centro de Investigación y Capacitación Agrícola (CICA), que en 1969 se constituye en el Departamento de Agricultura de la Universidad del Norte.

Desde sus inicios, esta unidad se dedicó al estudio sistemático de los problemas que afectaban los cultivos de los valles de Lluta, Azapa y Camarones. Así, los investigadores se encontraron con problemas fitosanitarios nunca antes estudiados en el país y recurrieron a novedosos métodos para analizar los ciclos vitales de insectos y nemátodos que destruían el esfuerzo productivo de los agricultores. Ya iniciada la década de los 70, se hizo imperativa la necesidad de divulgar la experiencia adquirida en los campos como resultado de los programas de investigación focalizados en cuatro cultivos: tomate, fréjol, alfalfa y maíz.

Así, en agosto de 1970, se publica el primer número de la revista IDESIA, cuya presentación fue hecha por el director del Departamento de Agricultura, don Juan F. Pacheco W., quien destacó, con gran visión de futuro, hace 50 años:

Pero creemos que es mucho más importante el concepto generalmente olvidado, de que estas 10.000 Hás. se cultivan todo el año, que pueden dar sorprendentes rendimientos, que se destinan al cultivo de "primores" para abastecer los grandes mercados consumidores del centro y del sur de Chile, además de los 100.000 habitantes del Departamento de Arica y, por último, que estas 10.000 Hás. pueden bien representar potencialmente, y desde luego mejor trabajadas, la producción de 30.000 o 50.000 y, hasta tal vez, 100.000 Hás. de suelo menos fértiles de latitudes australes.

En 1982, al crearse la Universidad de Tarapacá, pasa a denominarse Instituto de Agronomía. En 1998, con la experiencia de más de 25 años investigando los principales cultivos de la antigua región de Tarapacá y el sur del Perú, en una decisión estratégica que permitiría la formación de ingenieros agrónomos, el Instituto de Agronomía se transforma en Facultad de Agronomía y en 2006 cambia su nombre a Facultad de Ciencias Agronómicas.

Hoy, el desierto es considerado un laboratorio natural para aprender del manejo de cultivos frente
In this context, by the initiative of the Junta de Adelanto de Arica, the Laboratory of Investigation and Control of Plagues is created on October $9^{\text {th }}$, 1963. Later, in 1966, it was transformed into the Center for Agricultural Research and Training (CICA), which in 1969 became the Department of Agriculture of the Universidad del Norte.

From its beginnings, this unit was dedicated to the systematic study of the problems that affected the cultivations of the valleys of Lluta, Azapa, and Camarones. This way, researchers found phytosanitary problems never studied before in the country and resorted to novel methods to analyze insects and nematodes' vital cycles that destroyed farmers' productive effort. In the early 1970s, it became imperative to disseminate the experience acquired in the fields due to research programs focused on four crops: tomatoes, beans, alfalfa, and corn.

Therefore, in August 1970, the first issue of the magazine IDESIA was published, and was presented by the Director of the Department of Agriculture, Mr. Juan F. Pacheco W., who emphasized, with great vision, that it was 50 years ago:

We believe that the generally forgotten concept is much more important; these 10,000 hectares are cultivated all year round, they can give surprising yields, that they are destined for the cultivation of "primes" to supply the large consumer markets of the center and south of Chile, in addition to the 100.000 inhabitants of the Department of Arica and, finally, that these 10,000 hectares may well represent potentially, and certainly better worked, the production of 30,000 or 50,000 and, perhaps, even 100,000 hectares of less fertile soil in southern latitudes.

In 1982, when the Universidad de Tarapacá was created, it was renamed the Institute of Agronomy. In 1998, with the experience of more than 25 years investigating the main crops of the ancient region of Tarapaca and the south of Peru, in a strategic decision that would allow the training of agronomist engineers, the Institute of Agronomy is transformed into the Faculty of Agronomy and in 2006 it changes its name to the Faculty of Agronomic Sciences.

Today, the desert is considered a natural laboratory for learning about crop management in the face of climate change. The challenge for the coming years is to produce in an economically, socially, 
al cambio climático. El desafío para los próximos años es producir en forma sostenible desde el punto de vista económico, social y medioambiental. Los consumidores son cada vez más exigentes en su alimentación y están interesados en conocer los procesos de producción, donde el bienestar animal, el cuidado del medio ambiente y el respeto a las condiciones laborales de los productores son un factor determinante a la hora de elegir sus alimentos.

En estos 50 años de labor de divulgación del quehacer investigativo de las ciencias agronómicas por parte de la revista IDESIA, quisiera expresar mis más sinceras congratulaciones a todos aquellos académicos y académicas que han colaborado a lo largo de estos años para que esta publicación haya alcanzado los niveles de reconocimiento a nivel nacional e internacional que tiene hoy. Espero que en los años venideros se siga consolidando este camino en pos del reconocimiento internacional de la Región de Arica y Parinacota, como un área privilegiada a nivel mundial en el ámbito de la agricultura del desierto. and environmentally sustainable way. Consumers are increasingly demanding in their food and are interested in knowing the production processes, where animal welfare, environmental care, and respect for producers' working conditions are a determining factor in choosing their food.

In these 50 years of work of disseminating the research work of the agricultural sciences by the magazine IDESIA, I would like to express my most sincere congratulations to all those academics who have collaborated throughout these years so that this publication has reached the levels of national and international recognition that it has today. I hope that in the years to come, this path will continue to be consolidated in order to achieve international recognition of the Arica and Parinacota Region as a world level privileged area in the field of desert agriculture. 